\title{
Perception and attitude of pastoralists on the use and conservation of rangeland resources in Afar Region, Ethiopia
}

\author{
Minyahel Tilahun ${ }^{1}$, Ayana Angassa ${ }^{2,4^{*}},{\text { Aster } \text { Abebe }^{2} \text { and Alemayehu Mengistu }}^{3}$
}

\begin{abstract}
Introduction: Community perception plays a significant role in rangeland resource management. Traditional rangeland management practices by the pastoral communities are based on accumulated knowledge in connection to their local environment. Pastoralism played a vital role in food production and sustaining its inhabitants in arid environment for millennia. However, national policies and development interventions in East African pastoral systems have often overlooked pastoralism while centered on the modernization of agricultural sector for economic development and poverty reduction.
\end{abstract}

Methods: We used household survey, focus group discussion, key informant interview, and individual questionnaire to understand the perceptions and attitude of Afar pastoralists towards rangeland resource use and conservation practices, as well as impacts of development intervention on traditional rangeland resource use and conservation practices. The data were analyzed using index ranking and descriptive statistics.

Results: The results showed that livestock holding per household was higher on average ( $22.90 \pm 2.27$ Tropical Livestock Unit (TLU)) in the non-intervened woreda than in the intervened woreda ( $8.30 \pm 3.85 \mathrm{TLU})$ ). Respondents mentioned that livestock productivity was adversely affected by a number of factors such as invasion of Prosopis juliflora (Dergi Hara), shrinkage in the capacity of rangelands (Beadu and Bebea'), and recurrent droughts. Scarcity of grazing resources attributed to the invasion of Dergi Hara and drought created livestock feed crisis with strong implication on the livelihood of pastoralists. Our results showed that the traditional resource management practices such as mobility, herd splitting, and diversification had a role to contribute to the improvement of rangeland management and conservation of biodiversity. Traditional rules and seasonal-based grazing patterns of riversides during drought were perceived as key elements for rangeland resource management and conservation of rangeland resources in the study area.

Conclusions: Communities' perception showed that the traditional practices of rangeland management systems are effective and environmentally sustainable. In contrast, inappropriate development interventions put rangelands under severe pressure. Although development interventions were aimed at improving the condition of Afar rangeland, they could not bring any enduring solution in terms of improvement of rangeland resources.

Keywords: Perception and attitude, Pastoralists, Rangeland resources, Use and conservation, Development intervention

\footnotetext{
* Correspondence: ayana.angassa@gmail.com

${ }^{2}$ School of Animal and Range Sciences, Hawassa University, Hawassa, Ethiopia

${ }^{4}$ Department of Animal Science and Production, Botswana University of

Agriculture and Natural Resources, Gaborone, Botswana

Full list of author information is available at the end of the article
} 


\section{Introduction}

The anonymous Nigerian herder has expressed land in such a way that "land belongs to a vast family of which many are dead, few are living and countless members are still unborn". This expression is also shared by the Afar pastoralists of Ethiopia (Mohammed 2010). Extensive observations and continuous herding practices have helped pastoralists to acquire a detailed knowledge of their environment (Angassa et al. 2012). Over generations, pastoralists have a wealth of knowledge to sustain their livelihoods in arid environments (Megersa et al. 2014).

Community-based knowledge plays a significant role in rangeland resource management (Angassa et al. 2012). The traditional practices of rangeland management are based on meticulous and wise use of community's knowledge (Farm Africa 2009). In recent years, a growing body of literatures (Oba 1998; Angassa and Beyene 2003; Angassa and Oba 2008; Angassa et al. 2012) have tried to inform policy-makers and development practitioners to recognize community's knowledge for sustainable management of their environment. Previous studies (Feye 2007; Mohammed 2004, 2010; Angassa et al. 2012; Sulieman and Ahmed 2013) have also shown that communities' knowledge has a role to play in the advancement of scientific research and attainment of sustainable development goals.

Similar to trends in other parts of Africa, the Afar pastoralists of Ethiopia are experiencing considerable erosion of their traditional lifestyle during the last five decades (James et al. 2014). This is due to incessant appropriation of their prime grazing lands, particularly in the Awash valley, for large-scale commercial farms, game park, urban settlement with increasing trends of human and livestock populations (Mohammed 2004, 2010).

Despite the vital role of pastoralism as way of life in food production for its inhabitants in arid environment for millennia, pastoral societies are poorly recognized by national policies. National policies and development agenda in East African pastoral systems often overlooked pastoralism only focusing on modernization of the agricultural sector as engine of economic development and poverty reduction (Mohammed 2010). Successive governments of Ethiopia have been promoting large-scale agricultural intervention in pastoral areas (James et al. 2014). Development in pastoral areas has long been a contested concept (James et al. 2014), which is arguably the case in the context of Afar pastoralists. Previous studies (Solomon and Abebe 2014; James et al. 2014) have indicated that the promotion of irrigated agriculture has often contributed to the continued marginalization and resource depletion rather than improvement of communities' livelihood in Afar pastoral areas. According to the same authors, the view that pastoralism is an inefficient way of life, which should be replaced by sedentary agriculture, and as a result ignorance of local communities' participation in development interventions contributed to the unfavorable effects facing them today.

A number of studies (Stringer and Reed 2007; Teshome et al. 2010; Sulieman and Ahmed 2013) have suggested that recognizing pastoralists' perception and their goals could provide useful information for designing effective management and development programs. It further helps in ensuring sustainable management of rangeland resources thereby improving the livelihood of pastoralists in the region.

Although indigenous knowledge may provide a basis for developing alternative ways of managing resources at the grass root level, such knowledge has overlooked in different zones of Afar Region of Ethiopia. Since the last few decades, the expansion of large-scale agricultural farms, park reservation, and settlement has been given more emphasis than the traditional practices of rangeland management. Therefore, the objective of the study was (i) to understand the perceptions and attitude of Afar pastoralists towards rangeland resource use and conservation practices and (ii) to assess the impact of development intervention on traditional rangeland resource use and conservation practices.

\section{Methods}

\section{Study area and sampling}

The study was conducted in two woredas of zone III of Afar Regional State which is included in the Middle Awash basin, Northeastern Ethiopia. The Middle Awash basin is located on average at altitudes ranging from 500 to $600 \mathrm{~m}$ above sea level, and located between $9^{\circ} 30^{\prime}$ and $10^{\circ} 20^{\prime} \mathrm{N}$ and $40^{\circ} 30^{\prime}$ and $40^{\circ} 50^{\prime} \mathrm{E}$ (Farm Africa 2009). The area is largely covered by bush, shrub, and predominantly swamp vegetation. The indigenous vegetation is now replaced by Prosopis juliflora tree. Areas away from the Awash River have scattered clumps of short and thorny Vachelia and Senegalia trees with few grasses.

In the survey, a three-stage sample design was adopted. Firstly, two adjacent woredas, Amibara and Gewane, were selected purposely for this particular study. The woredas are similar in terms of ethnicity, production system and agro-ecology. They are predominantly inhabited by the Afar pastoralists. Minor differences between the two districts refer to the degree and frequency of implementation of development interventions. In this study, intervened and non-intervened were used to represent Amibara and Gewane woredas, respectively. "Intervened" represents relatively large and frequent governmental organization (GO) and nongovernmental organization (NGO) interventions with 
increased private farming and implementation of settlement programs, whereas "non-intervened" represents kebeles which were relatively free from implementation of large-scale farming both at private and state levels, as well as free from implementation of settlement program and NGO interventions. This study gives special attention to interventions related to large-scale commercial agriculture run by the private sector and the state, presence or absence of settlement programs, and NGO interventions. The second stage was purpose-oriented selection of kebeles (two from each woredas; Adbaro and Beida from Gewane; Alaysumela and Eeble from Amibara woreda) and was made to ensure meaningful representation of the study area. During the time of data collection, eight kebeles of Amibara woreda were affected by flood from the Awash River. They could not get into a choice to represent the woreda. Eventually, HHs were randomly selected from each sample kebeles based on pastoral HHs' list obtained from kebeles administrators.

Randomly selected pastoral HHs from the four kebeles (Adbaro, Beida, Alaysumela, and Eeble) were used for information related to this study. The interview was undergone following complete lists of pastoral HHs from the selected kebeles. A total of 100 pastoral HHs were selected from the two sample woredas, i.e., $25 \mathrm{HHs}$ per kebele.

\section{Data collection and analysis}

Focus group discussions (FGDs) and key informants' interviews (KIIs) were conducted using a Participatory Rural Appraisal (PRA) tools (Mercado 2006). An openended, discovery-oriented, and semi-structured questionnaire was used to understand a person's insight, feeling, thought, and opinion about rangeland resource availability, land ownership, impact of external development interventions, and perception towards different trends of social, economic, and cultural aspects of pastoral communities. Different groups of the society who have the knowledge to show what the conditions look like in Afar rangeland, i.e., elders, experts in rangeland management, and administrative staffs of the study area participated in FGDs and KIIs. For the questionnaire, a household was taken as a unit of analysis. Wealth status in the study area was categorized in terms of livestock holding. An individual was considered as wealthy, if and when he/she owned above 5 camels, between 15 and 20 cattle, and above 50 goats which results in an estimate of 22.25 TLU. An individual who owned no camel, 5 or fewer cattle, and between 10 and 20 goats, and who was engaged in daily labor was considered as poor, with an estimate of $5 \mathrm{TLU}$; those who fall in the middle of the two considered as average which was 14.7 TLU. For meaningful wealth status comparison between the two woredas, the average of the two woreda characteristics for wealth was taken to evaluate the livelihood condition of HHs. Figure 1 presents the wealth category of households from the study woredas. The $\mathrm{HHs}$ which fall in the average wealth category were relatively similar in both woredas while HHs that fall in the poor category were higher $(48 \%)$ for the intervened woreda.

The questionnaire was consisted of both close- and open-ended questions. Prior to conducting the actual survey, the questionnaire was translated to the local language "Afaraf", and objectives of the survey was explained and discussed with the informants in order to ensure their cooperation. Similarly, the semi-structured questionnaire was pre-tested and all necessary adjustments were made accordingly prior to its use for the final HHs survey. Household's information, livelihood of pastoralists, and various rangeland resource management practices were included in the questionnaire. In addition, pastoralists' perceptions towards threats to rangeland resources and impacts of external development interventions, and values of indigenous knowledge of the Afar pastoralists were served for providing insights on how these changes happened. Moreover, it is important to rely on local communities' knowledge to understand about the direction of change in the condition of communal rangelands in the study areas. A total of four trained enumerators (one for each kebeles) were hired for conducting the survey under close supervision of the principal researcher. Besides the researcher, two development agents (i.e., one for each woreda) were also hired to make a close supervision on the data collection process at a household level. Data were collected between the months of February and March 2015.

Completed questionnaires were first checked and coded. After careful scrutiny, the data were entered into a computer and analyzed using SPSS software programs. Specifically, statistics like percentages, mean, standard deviation, cross-tabulation, and projections were employed during analysis and interpretation of pastoralists' perception and attitude towards the use and conservation of rangeland resources. Data related to causes of rangeland degradation, local indicators of rangeland degradation, and consequences of rangeland degradation were analyzed using a rank index method (Musa et al. 2006). The rank index was computed as follows:

$$
\begin{aligned}
\text { Index }= & R_{n} * C_{1}+R_{n-1} * C_{2} \ldots+R_{1} * C_{n} / \sum R_{n} * C_{1} \\
& +R_{n-1} * C_{2} \ldots+R_{1} * C_{n} ;
\end{aligned}
$$

where $R_{n}=$ value given for the least ranked level (example if the least rank is 5 th, then $R_{n}=5, R_{n-1}=4$, and ..., $R_{1}=1$ ); $C_{n}=$ counts of the least ranked level (in the above example, the count of the 5 th rank $=C_{n}$, and 


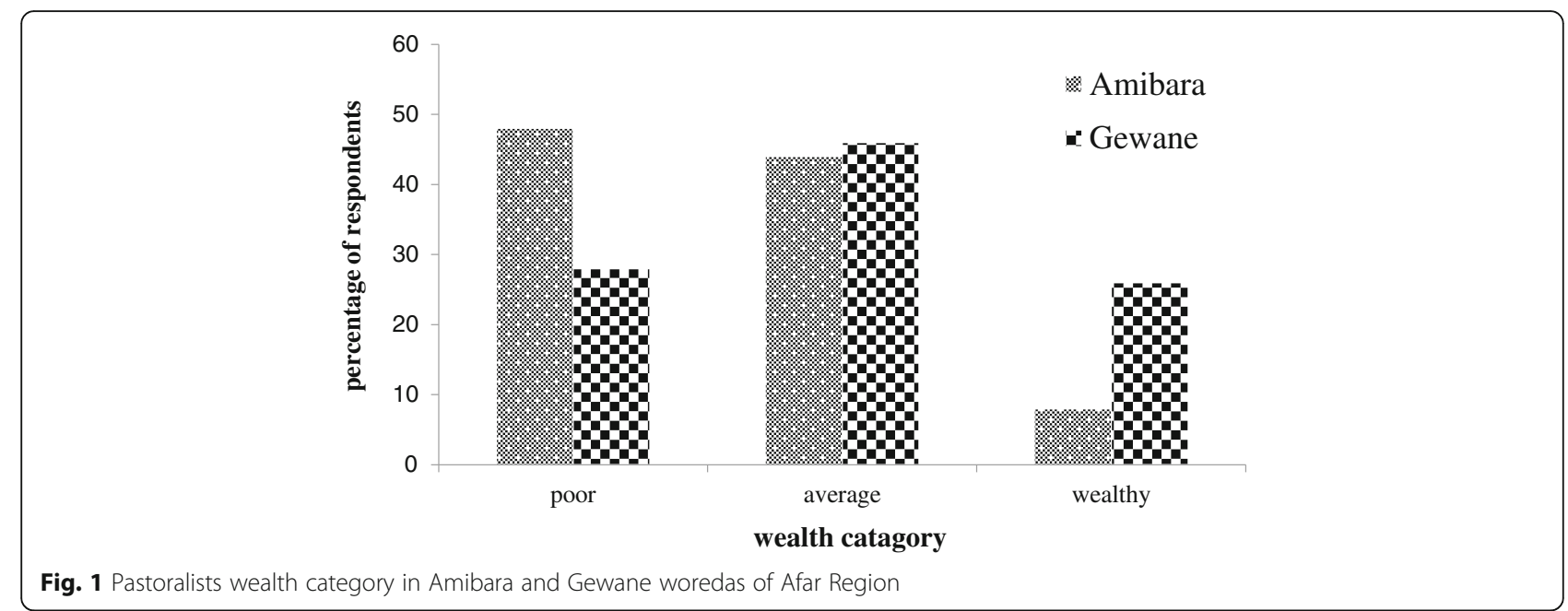

the count of the 1st rank $=C_{1}$ ). The opposite matching for $R$ and $C$ values can be presented as follows:

$R_{1}$ for $R_{n}, R_{2}$ for $R_{n-1} \ldots, R_{n}$ for $R_{1}$ and

$C_{1}$ for $C_{n}, C_{2}$ for $C_{n-1}, \ldots, C_{n}$ for $C_{1}$.

\section{Results}

\section{Changes in income source during different Afar seasons}

Figure 2 presents pastoralists' income generation at different seasons of the year in the study woredas. Respondents perceived that the major sources of income in the intervened woreda were from daily labor as compared to the nonintervened woreda. During the cold and dry season, about
$60 \%$ of the respondents in the intervened woreda used to generate their income from daily labor, whereas only $20 \%$ of the respondents in non-intervened woreda generated their income from daily labor. Income generation through livestock and livestock product sale rised at an accelerating rate, and almost all livestock holders sold livestock before the end of the dry season in the intervened woreda. The proportion of household participated in livestock sell was low (80 \%) for the non-intervened woreda as compared to the intervened woreda with a moderate inclination.

\section{Livestock holding and composition}

Table 1 presents mean livestock holding per household in the study area. Mean livestock holding in terms of
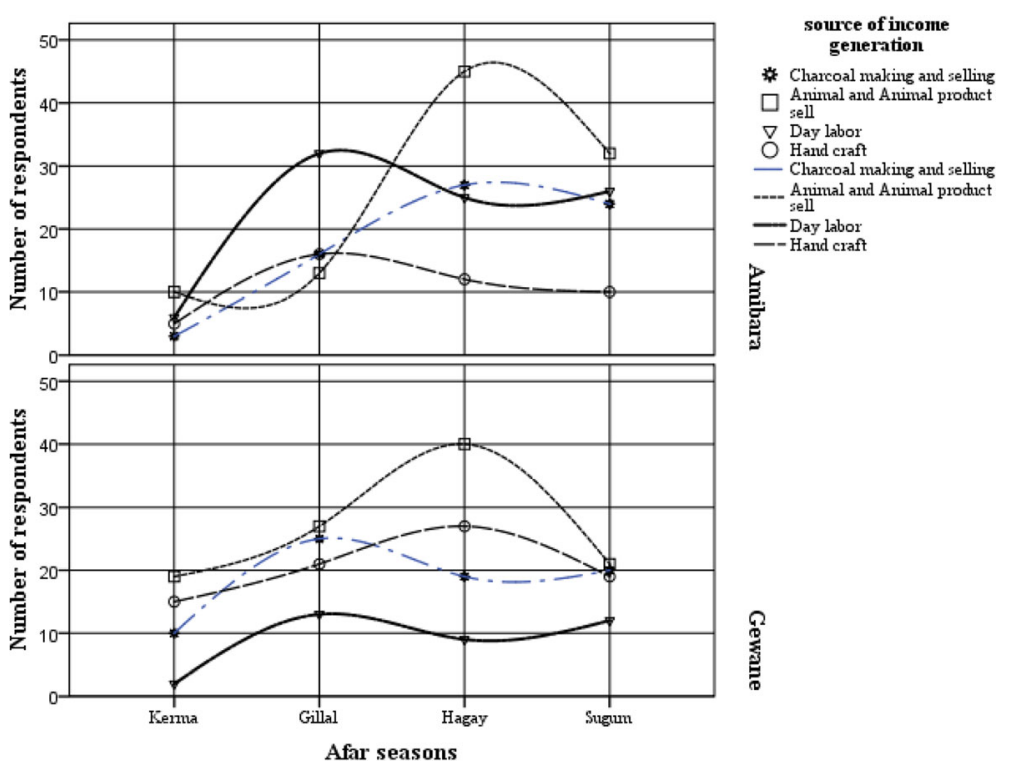

Fig. 2 Pastorals income generation at different seasons. Kerma (Long rainy season), Gillal (Cold and dry season), Hagay (Dry season) and Sugum (Short rainy season). Note: the total number of respondents for each season income generation could be ranges from 0(i.e., no respondent select the given choice) to 200 (i.e., all respondents (50) from the given study woreda choose all the choices (4)) 
Table 1 Livestock holding per household by major species in the study woredas in Afar Region of zone III

\begin{tabular}{|c|c|c|c|}
\hline \multirow[t]{2}{*}{ Livestock type } & \multicolumn{2}{|c|}{ Livestock holding (TLU) } & \multirow[t]{2}{*}{ Total } \\
\hline & Amibara $^{a}$ & Gewane $^{b}$ & \\
\hline Cattle & $1.71 \pm 3.01$ & $7.66 \pm 0.80$ & $4.68 \pm 1.90$ \\
\hline Camel & $0.74 \pm 0.26$ & $2.84 \pm 0.43$ & $1.79 \pm 0.34$ \\
\hline Goat & $4.89 \pm 0.41$ & $10.46 \pm 0.81$ & $7.66 \pm 0.62$ \\
\hline Sheep & $0.96 \pm 0.17$ & $1.94 \pm 0.24$ & $1.43 \pm 0.21$ \\
\hline Major livestock & $8.30 \pm 3.85$ & $22.90 \pm 2.27$ & $15.90 \pm 3.08$ \\
\hline
\end{tabular}

Major livestock represent most commonly owned livestock species in the study area. The TLU values for different species of animals are 1.0 for camel, 0.7 for cattle, and 0.1 for goat/sheep (ILCA, 1992)

antervened woreda

${ }^{\mathrm{b}}$ Non-intervened woreda

Tropical Livestock Unit (TLU) per household was higher for the non-intervened woreda $(22.90 \pm 2.27 \mathrm{TLU})$ than that of the intervened woreda $(8.30 \pm 3.85 \mathrm{TLU})$. The Afar pastoralists were known for their cattle herding, although the situation is becoming reversed currently. On average, a higher proportion $(7.66 \pm 0.80 \mathrm{TLU})$ of goats were held by pastoralists, followed by cattle $(4.68 \pm 1.90$ TLU), sheep, and camel in the study areas. From the proportion of average livestock holding, pastoralists in the non-intervened woreda possessed the largest proportion of all livestock species as compared to the intervened woreda (Table 1).

\section{Available feed resource in the study area}

Table 2 presents major feed resources available in the study area. Our results showed that $32 \%$ of the respondents from the intervened woreda and $14 \%$ from the non-intervened woreda perceived that they were using crop residue as major feed sources for their livestock. Similarly, $34 \%$ of the respondents from the intervened woreda mentioned that they rely on grasses and bushes as major feed resources for their livestock. But the proportion was increased to $44 \%$ for the non-intervened woreda. This was due to the improved condition of rangeland and presence of grazing reserves (Geso) for livestock in the non-intervened woreda.

Table 2 Major feed resources as perceived by respondents from the study woredas in Afar Region ( $N=100$ : Amibara $=50$ and Gewane = 50)

\begin{tabular}{llll}
\hline Major feed resources & \multicolumn{2}{l}{ Respondents (\%) } & Total N (\%) \\
\cline { 2 - 3 } & Amibara & Gewane $^{\text {b }}$ & \\
\hline Grass only & 22 & 30 & $26(26)$ \\
Bushes only & 12 & 12 & $12(12)$ \\
Grass and bushes & 34 & 44 & $39(39)$ \\
Crop residues & 32 & 14 & $23(23)$ \\
\hline
\end{tabular}

antervened woreda

${ }^{\mathrm{b}}$ Non-intervened woreda

\section{Traditional rangeland resource management}

Pastoralists' perception towards rangeland resource management systems is described in Table 3 . The majority of respondents (59\%) agreed that the traditional resource management practices were in a declining trend. Respondents also reported that the size of farm lands under commercial crop cultivation and number of private and government sectors involved in such activities were rapidly increased. The majority of respondents (90\%) in the intervened woreda reported that the condition of the rangelands was more deteriorated with the rapid increase of inappropriate development interventions (Table 3). The majority of our respondents (94\%) in the intervened woreda perceived that the size of communal rangelands was greatly reduced (Table 3). Generally, almost all respondents (100 \%) from both woredas reported that the condition of their rangelands was highly deteriorated.

The results showed that the majority of respondents (75\%) mentioned that their income-generating sources were diversified. Weak institutional support on livestock production $(77 \%)$ was perceived as one of the reasons for the declining trends of traditional resource management in the study area.

Afar traditional resource management practices and impacts of development interventions in Afar Region are presented in Table 4. According to respondents' perception, herders used to apply indigenous rangeland

Table 3 Pastoralists' perception on trends of rangeland resource management system in Afar Region ( $N=100$ : Amibara $=50$ and Gewane = 50)

\begin{tabular}{|c|c|c|c|}
\hline \multirow[t]{2}{*}{ Trends of rangeland management } & \multicolumn{2}{|c|}{ Respondents (\%) } & \multirow{2}{*}{$\begin{array}{l}\text { Total } \\
N(\%)\end{array}$} \\
\hline & Amibara $^{a}$ & Gewane $^{\mathrm{b}}$ & \\
\hline $\begin{array}{l}\text { Trends of traditional management } \\
\text { systems are declining }\end{array}$ & 66 & 52 & $59(59)^{c}$ \\
\hline $\begin{array}{l}\text { Livestock number, body condition, } \\
\text { and productivity are deteriorating }\end{array}$ & 100 & 100 & $100(100)$ \\
\hline $\begin{array}{l}\text { Farm laborers and settlers are } \\
\text { increasing }\end{array}$ & 66 & 42 & $54(54)$ \\
\hline $\begin{array}{l}\text { Trends of large-scale agricultural } \\
\text { farms are increasing }\end{array}$ & 90 & 46 & $68(68)$ \\
\hline $\begin{array}{l}\text { Communal rangeland is rapidly } \\
\text { shrinking }\end{array}$ & 94 & 86 & $90(90)$ \\
\hline Settlement programs are expanding & 96 & 50 & $73(73)$ \\
\hline $\begin{array}{l}\text { Condition of communal rangeland } \\
\text { is deteriorating }\end{array}$ & 100 & 100 & $100(100)$ \\
\hline $\begin{array}{l}\text { Valuable plant species are } \\
\text { disappearing }\end{array}$ & 86 & 90 & $88(88)$ \\
\hline Income diversification is increasing & 82 & 68 & $75(75)$ \\
\hline $\begin{array}{l}\text { Support from GOs and NGOs is } \\
\text { weakening }\end{array}$ & 68 & 86 & $77(77)$ \\
\hline
\end{tabular}

IIntervened woreda

${ }^{\mathrm{b}}$ Non-intervened woreda 
Table 4 Traditional resource management practices and impacts of development interventions in Afar Region ( $N=100$ : Amibara $=50$ and Gewane $=50$ )

\begin{tabular}{|c|c|c|c|}
\hline \multirow[t]{2}{*}{ Traditional management practices } & \multicolumn{2}{|c|}{ Respondents (\%) } & \multirow{2}{*}{$\begin{array}{l}\text { Total } \\
N(\%)\end{array}$} \\
\hline & Amibara $^{a}$ & Gewane $^{\mathrm{b}}$ & \\
\hline Use of herd splitting & 90 & 100 & $95(95)$ \\
\hline Use of herd diversification & 54 & 68 & $61(61)$ \\
\hline Use of grazing reserves & 26 & 58 & $42(42)$ \\
\hline Use of fire & 22 & 24 & $23(23)$ \\
\hline Use of mobility & 90 & 100 & $95(95)$ \\
\hline $\begin{array}{l}\text { Importance of traditional practices of } \\
\text { rangeland resource use and conservation }\end{array}$ & 46 & 80 & $63(63)$ \\
\hline $\begin{array}{l}\text { Development interventions were not } \\
\text { participatory }\end{array}$ & 80 & 88 & $84(84)$ \\
\hline $\begin{array}{l}\text { Development interventions were less } \\
\text { successful than customary institutions }\end{array}$ & 78 & 90 & $84(84)$ \\
\hline $\begin{array}{l}\text { Development interventions were not } \\
\text { compatible with pastoralists support } \\
\text { interest }\end{array}$ & 94 & 82 & $88(88)$ \\
\hline
\end{tabular}

Intervened woreda

${ }^{\mathrm{b}}$ Non-intervened woreda

management practices for centuries. The majority of our respondents $(95 \%)$ perceived that mobility and herd splitting was considered as the most practiced management systems by Afar pastoralists, whereas use of fire $(23 \%)$ and putting aside grazing land (42\%) for dry season or drought year grazing reserves were the least practiced in traditional rangeland management practices. Out of the total respondents, $63 \%$ of the respondents believed that traditional rangeland management practices would continue to serve the Afar pastoralists in their future rangeland resource use and conservation.

The majority of respondents $(84 \%)$ perceived that development interventions overlooked the participation of customary institutions. Similarly, most respondents $(88$ \%) reported that development projects did not favor pastoralists' interest and incompatible with the ecological potential of arid environments. Many development programs that focus on improving the livelihood condition of pastoralists were implemented in the study area. However, respondents questioned the environmental compatibility of those development programs in relation to the ecological potential of the region.

\section{Perceived threats on rangelands and livestock production}

Table 5 describes primary threats to the grazing land and livestock resources. Respondents from the study area ranked bush encroachment in terms of the expansion of invasive plant species mainly $P$. juliflora as a major threat to the quality and quantity of rangeland resources. Other factors like crop cultivation, overgrazing, and climate change took the rest consecutive ranks.
Table 5 Threats to grazing land quality and capacity, as well as livestock performance as perceived by pastoralists

\begin{tabular}{|c|c|c|c|c|}
\hline \multirow[t]{2}{*}{ Threat } & \multicolumn{2}{|l|}{ Amibara $^{a}$} & \multicolumn{2}{|l|}{ Gewane $^{\mathrm{b}}$} \\
\hline & $N$ (index) & Rank & $N$ (index) & Rank \\
\hline Overgrazing & $91(0.18)$ & 3 & $84(0.17)$ & 3 \\
\hline Bush encroachment & $180(0.36)$ & 1 & $187(0.37)$ & 1 \\
\hline Climate change & $87(0.18)$ & 4 & $74(0.15)$ & 4 \\
\hline Crop cultivation & $142(0.28)$ & 2 & $152(0.31)$ & 2 \\
\hline Shrinkage of grazing land ${ }^{c}$ & $156(0.21)$ & 3 & $158(0.21)$ & 3 \\
\hline Bush encroachment ${ }^{c}$ & $188(0.25)$ & 2 & $181(0.24)$ & 2 \\
\hline Drought $^{c}$ & $226(0.30)$ & 1 & $225(0.30)$ & 1 \\
\hline Disease $^{c}$ & $108(0.14)$ & 4 & $106(0.14)$ & 4 \\
\hline Tick $^{c}$ & $72(0.10)$ & 5 & $80(0.11)$ & 5 \\
\hline
\end{tabular}

antervened woreda

${ }^{\mathrm{b}}$ Non-intervened woreda

'Threats to livestock performance

The majority of respondents from both study areas ranked drought as the primary threat to livestock production followed by bush encroachment and shrinkage of the communal grazing lands.

\section{Drawbacks of development interventions on rangeland resource conservation and pastoralists' livelihood}

Table 6 describes the impact of development intervention on the Afar rangelands. Respondents perceived and ranked shrinkage of grazing lands as problem number one. Respondents ranked low performance of livestock and rangeland degradation as third and fourth factors in both woredas, while conflict was ranked by respondents differently in both cases.

\section{Compatibility of development policies with pastoral livelihood strategies}

The relationship between pastoralists' land use demands of the different wealth categories are presented in Fig. 3. The majority of resource-poor pastoralists (80 \%) among

Table 6 Impact of development intervention as ranked by respondents in the study area $(N=100 ;$ Amibara $=50$ and Gewane =50)

\begin{tabular}{lllllll}
\hline Impacts & Amibara $^{a}$ & & & Gewane $^{\mathrm{b}}$ & \\
\cline { 2 - 3 } \cline { 6 - 7 } & $N$ (index) & Rank & & N (index) & Rank \\
\hline Shrinkage of grazing land & $222(0.30)$ & 1 & & $209(0.28)$ & 1 \\
Death of livestock & $190(0.25)$ & 2 & & $78(0.11)$ & 5 \\
Low performance of livestock & $147(0.20)$ & 3 & & $154(0.21)$ & 3 \\
Rangeland degradation & $100(0.13)$ & 4 & & $108(0.15)$ & 4 \\
Conflict & $89(0.12)$ & 5 & & $186(0.25)$ & 2 \\
\hline
\end{tabular}

antervened woreda

${ }^{\mathrm{b}}$ Non-intervened woreda 

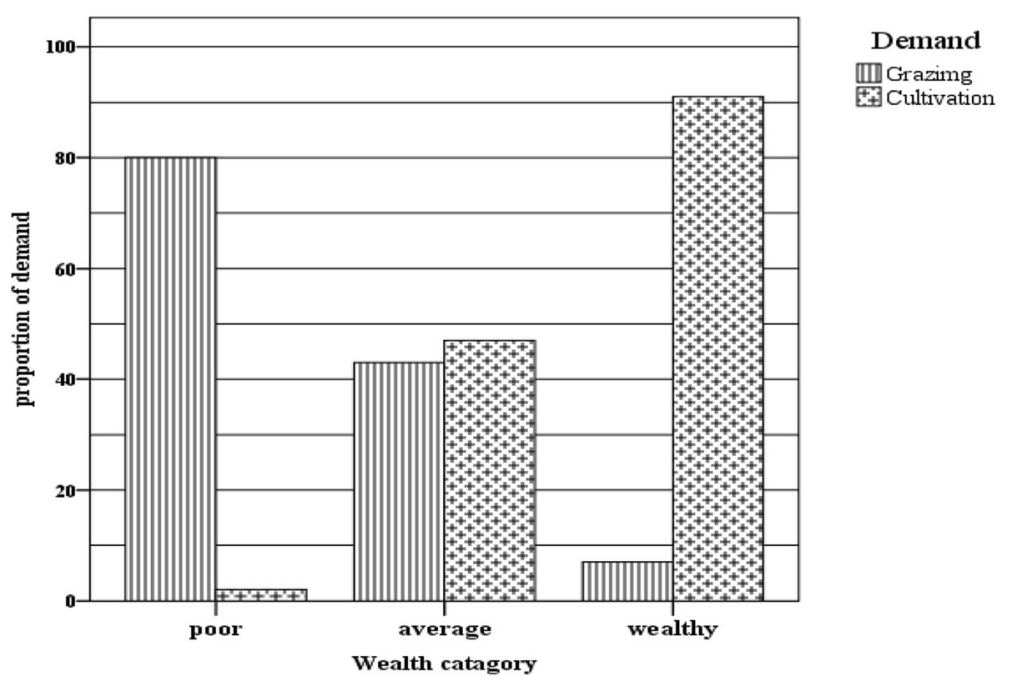

晸 Grazimg

Note: - poor (5 TLU); average (14.7 TLU); rich/wealthy (22.25 TLU)

the poor wealth category preferred to use rangelands for irrigated cultivation than livestock production. However, the majority of respondents (93\%) among rich wealth group demanded the land for livestock grazing than crop cultivation.

In addition, land demand for cultivation and grazing among respondents showed and implied those who prefer to use land both as crop land and grazing land (agro-pastoralism) lied in between the poor wealth category (5 TLU) and average (14.7 TLU) wealth group.

\section{Discussion}

Traditional lifestyles of Afar pastoralists have often evolved in harmony with the nature of local environmental conditions. Protecting the rights of the pastoral society ensures that they remain as guardians of the rangeland resources. Land ownership right has been a critical issue in the case of Afar pastoralists in Ethiopia. From interviews with key informants, the reasons for implementing different interventions in pastoral areas might be attributed to the expectation that land is more abundant in these areas. However, such anticipation may further contribute to the fragmentation of the communal rangelands and creation of private settlement together with the expansion of large-scale agriculture. Similarly, Berhanu et al. (2013) state that increase in population growth because of state organized resettlement had resulted in the reduction of land holding per household. This study confirmed that pastoralists in the intervened woreda prefer governmental interference in terms of land use system. According to elders and key informants' observations, dependency on emergency food aid in times of drought coupled with weakening of the traditional resource management system are major driving forces for the interference in pastoral land ownership rights. Livestock holding in terms of Tropical Livestock Unit (TLU) $(15.59 \pm 3.05)$ for the present study area is much higher than that reported by Tsegaye (2010) in the northern part of Afar $(6.3 \pm 6.4)$ and Teshome et al. (2010) in the southern part of Oromia Region in Rayitu district $(10.3 \pm 0.62)$. However, the finding of our result from the intervened woreda is similar to the above stated results of different scholars from different pastoral areas of Ethiopia. This is because the study was conducted in pastoral areas whose major income sources were livestock production, where livestock is also a sign of prestige for pastoral households. Similarly, Berhanu et al. (2013) have reported a higher number of livestock $(22.31 \pm 16.40)$ and herd composition in Bench-Maji zone of southwest Ethiopia. On the other hand, a record on livestock holding in Afar Region has shown a declining trend in major livestock species (i.e., camel, cattle, goat, and sheep) from 5.86 to 1.13 in 2012/2013 (CSA 2012/13).

Previous studies (Kassahun 2006; Teshome et al. 2010; Megersa et al. 2014) have shown that the dependency on small ruminant herding makes more effective use of vegetation resources and often more profitable with a predominance of female animals. Respondents' observations show that shrinkage of grazing resources (i.e., scanty access to pasture and reduced grazing capacity) is the main reason for the declining trend in livestock holdings per household. Our findings show that Afar pastoralists were forced to diversify their livestock species by including drought-tolerant species such as goats and camels, which can be easily converted into cash in terms of income generation. A similar situation is also 
observed in Borana pastoral areas by Megersa et al. (2014) that suggest that the declining trends in livestock production are probably related to the shrinkage of grazing lands and change in climate.

Tafere and Teklu (2013) have shown the consequence of inappropriate interventions on the future of pastoralism by using pastoralists' expression as follows: "once you lose your original trail of tradition, the enemy takes advantage of your resources". Similarly, others (Feye 2007; Abebe et al. 2011) have shown that the traditional system of resource management (i.e., mobility) is an adaptive and coping strategy developed by pastoral societies to overcome the problem of feed scarcity and limited access to water in arid environments. For example, Abebe et al. (2012) have indicated that herd diversification by Borana pastoralists were derived by shifts in vegetation from grassland to woodland. Similarly, Megersa et al. (2014) have argued about a progressive shift from centuries old socio-cultural cattle pastoralism to multispecies herding with a focus on more droughttolerant livestock type. In the last five decades, traditional management practices in the study area are greatly affected by external development interventions, bush encroachment by Prosopis juliflora, conflict over resources and drought-related climatic impacts. In particular, earlier studies (Mohammed 2004, 2010; Tsegaye 2010) have shown that development-related interventions are major drivers of change in traditional ways of resource management. Others (Fantaye and Kwesi 2012; Tafere and Teklu 2013) have also reported that mobility in Afar pastoral area is greatly influenced by human interventions such as settlement, expansion of large-scale agricultural production, and allocation of the prime grazing areas for national park. Mohammed (2010) expressed the beginning of intervention in Afar Region as "Rape of the Afar pastoral land". Behnke and Kerven (2011) have argued that inappropriate development programs may not be a solution rather a cause of increased instability in pastoral livelihood support systems that are already exposed to significant rainfall, disease, and security risks. Our results are consistent with the work of Tafere and Teklu (2013) and Berhanu et al. (2013), suggesting that government activities are curtailing pastoralist mobility through settlement programs. Similarly, Solomon and Abebe (2014) argue that the current system of land administration greatly weakened the traditional practices of pastoral land use. In recent years, most scholars (e.g., Mohammed, 2004, 2010; Feye 2007; Tsegaye 2010; Angassa et al. 2012; Berhanu et al. 2013) have commented that pastoral societies in different parts of Ethiopia have less benefited or not at all profited from their common resources due to inappropriate intervention. In general, respondents' views indicate that development interventions negatively affected the condition of rangeland resources and livelihood of pastoralists. This is attributed to the expansion of commercial largescale agriculture, followed by conflict and death of livestock in the non-intervened and intervened woredas. Kloos (1982) expresses this as follows: "The idea was to provide irrigated land, training and services on the margins of commercial plantations for would-be Afar settlers who were known as 'outreach growers'". Tafere and Teklu (2013) have also shown that the attitude of pastoralists' towards their resources as "Afar do not joke about four assets: religion, women, land and livestock". As a whole, most elder participants in the FGDs believe that development interventions have not focused on improving the livelihood of every individual; rather, few members of the society are getting the benefit from rangeland resources. Tsegaye (2010) states that due to the impact of development intervention for the last five decades, the Afar rangelands are dramatically changed. Similarly, Berhanu et al. (2013) in Menit-Shasha district of Bench-Maji zone southwest Ethiopia and Solomon and Abebe (2014) in different pastoral areas of Ethiopia have reported that competition for land threatened the rights and access of pastoral communities to open pasture by displacing them from their original grazing lands, which resulted in interests of conflicts and competition over resources between neighboring tribes and clans. According to respondents' observations, there is greater competition for land use among mobile pastoralists, settlement programs, and large-scale agricultural investments in the study areas.

According to James et al. (2014), the envisaged plantation economy would displace many pastoral inhabitants; however, neither the settlement nor shifting the pastoral livelihood to out-grower farmers became successful. From the result of this study, impacts of external development intervention can easily be explained, depending upon the shrinkage and degradation of communal grazing land and creation of pastoralists that do not support the livelihood of their HHs by themselves. Pastoralists are now clearly accustomed to major interventions, key actors, impacts, and indicators which could lead to deterioration of natural resources and traditional management system. The result of our finding is in line with the findings of others (Mohammed 2004, 2010; Tsegaye 2010, Feye 2007; Angassa et al. 2012; Berhanu et al. 2013) in pastoral areas of Ethiopia. Flintan (2011) argues that the existence of livestock migration routes in the Horn of Africa (HoA) is greatly threatened by commercial agriculture.

Pastoralists' perception and observations made towards rangeland condition in the present study support earlier results (Bekele and Kebede 2014; Teshome et al. 2010; Mohammed 2004, 2010; Feye 2007; Tsegaye 2010). This suggests a gradual decline in rangeland condition 
as a result of increased population pressure, spread of bush encroachment, shrinkage of grazing areas, ethnic conflicts, and loss of wet season grazing lands to cultivation, ranching, private enclosures, and parks. Overall, our findings suggest that local community participation is crucial for successful implementation of any development program, optimal use of resources, and long-term environmental sustainability.

\section{Conclusions}

Afar pastoralists have a detailed knowledge of their environment that helped them to device adaptive strategies to make use of scarce natural resources for centuries. Indigenous knowledge of the local community is the key to keep the natural environment in balance and preserve the biodiversity of rangeland ecosystems. Increased development intervention was potentially a major challenge for the rangelands of Afar. Pastoralists claimed that the declining patterns of grazing resources over the years are a sign of threat to the existence of pastoralists in the region. Encroachment of large-scale agricultural schemes is among the emerging issues for the loss of customary practices in the case of Afar pastoralists. The expansion of such schemes deprives pastoralists from their resting place during dry season and drought year. Pastoralists expressed their fear that the remaining dry season grazing lands could be further allocated for the ever expanding large-scale agriculture investment and settlement programs. Generally, development intervention during the last five decades greatly affected the condition of Afar rangelands and communities' way of life. The present results confirmed that the number and performance of livestock are declining due to the shrinkage of grazing lands as agricultural investments are expanding. Livestock diversification from camel dominance towards small ruminant herding emerged as an adaptation strategy to enormous challenges as a result of decades of inappropriate development interventions and impacts of climate change on the livelihood of Afar pastoralists. Since development intervention initiated to create a change in the livelihood of the selected society, an improvement should have to be seen in the short or the long-term. Development interventions that have been implemented in the study area were not successful, mainly due to ignorance of the indigenous knowledge of the Afar society (Mohammed 2004, 2010). Continued implementation of those development interventions without the participation of the host community resulted in the reduction of communal grazing lands and access to communal resources. Current government strategy in changing Afar pastoralists to agro-pastoral way of life should follow the livestock holding of pastoralists which helps them to control the direct shift to pastoralism or agro-pastoralism. The impact of those development interventions is eminent that it has been eroding and creates lack of trust on centuries of traditional resource management practices. This study creates an insight into sustainable rangeland resource use and conservation practices that can be ensured if the balance between the traditional and modern systems of resource utilization could be maintained. We suggest that integration of the indigenous and modern systems of land management would have a positive implication on the conservation and sustainable use of rangeland resources while maintaining the social and cultural values of the community in balance.

\section{Acknowledgements}

The authors acknowledge those pastoral communities and officials in the study areas for their cooperation and assistance during fieldwork. We also thank the Ethiopian Ministry of Agriculture for the financial assistance to conduct the research work.

\section{Authors' contributions}

MT conducted the field research, analyzed the data, and drafted the manuscript. AAn and AAb designed the research, interpreted the results, and helped in the manuscript writing. AM participated in the write-up of the manuscript and interpretation of the results. All authors revised the manuscript, and read and approved the final version.

\section{Competing interests}

The authors declare that they have no competing interests.

\section{Author details}

${ }^{1}$ College of Agriculture and Natural Resources, Wolkite University, Gubrei, Ethiopia. ${ }^{2}$ School of Animal and Range Sciences, Hawassa University, Hawassa, Ethiopia. ${ }^{3}$ Forage and Rangeland Scientist, Urael Branch, P.O. Box 62291, Addis Ababa, Ethiopia. ${ }^{4}$ Department of Animal Science and Production, Botswana University of Agriculture and Natural Resources, Gaborone, Botswana.

Received: 10 June 2016 Accepted: 27 October 2016

Published online: 09 November 2016

\section{References}

Abebe A, Lars OE, Oyestin H, Torrnod A, Tolera A (2011) Pastoralists' perception of feed scarcity and livestock poisoning in southern rangelands, Ethiopia. Tropical Animal health and Production 44:149-157

Abebe A, Tolera A, Oyestin H, Torrnod A, Lars OE (2012) Seasonal variation in nutritive value of some browse and grass species in Borana rangeland, Southern Ethiopia. Tropical and Subtropical Agroecosystems 15:261-271

Angassa A, Beyene F (2003) Current range condition in southern Ethiopia in relation to traditional management strategies: the perceptions of Borana pastoralists. Tropical Grasslands 37:53-59

Angassa A, Oba G (2008) Herder perception on impacts of range enclosure, crop farming, fire ban and bush encrochment on the Rangelands of Borana, southern Ethiopia., pp 201-215

Angassa A, Oba G, Stenseth NC (2012) Community-based knowledge of indigenous vegetation in arid African landscapes. The Journal of Sustainable Development 8:70-85

Behnke R, Kerven C (2011) Replacing pastoralism with irrigated agriculture in the Awash Valley, north eastern Ethiopia: counting the costs. Paper presented at the International Conference on the Future of Pastoralism. 21- 23 March 2011. Addis Ababa

Bekele N, Kebede G (2014) Rangeland degradation and restoration in semi-arid areas of Southern Ethiopia: the case of Borana rangeland. International Journal of Environmental Sciences 3(2):94-103

Berhanu Y, Beyene F, Negatu L, Angassa A (2013) Influence of resettlement on pastoral land use and local livelihood in southwest Ethiopia. Tropical and Subtropical Agroecosystems 16:103-117

Central Statistical Agency (CSA) (2012/13) Agricultural sample survey. Statistical bulletin 570. Addis Ababa, Ethiopia, CTR publication. p 194 
Fantaye D, Kwesi SG (2012) Traditional authority and modern hegemony: peacemaking in the Afar region of Ethiopia., pp 75-98

Farm Africa (2009) A livelihood baseline survey in Amibara and Gewane woredas of Afar region. The Afar Prosopis Management Project document. Final report 1., p 119

Feye Y (2007) Pastoralists perception towards range resource utilization and range condition assessment in Gewane District of Afar Regional state, Ethiopia. Msc Thesis. School of Graduate studies, Haramaya University. p 65-66

Flintan F (2011) Broken lands, broken lives? Causes, processes and impacts of land fragmentation in the rangelands of Ethiopia, Kenya and Uganda. For REGLAP (Regional Learning and Advocacy Programme). Save the Children USA, Nairobi

James K, Michago WS, Eid A, Admasu LK (2014) Large scale land deals in Ethiopia: scale, trends, features and outcomes to date. IDRC and IIED, London, p 62

Kassahun A (2006) Impact of rangeland degradation on the pastoralist production system, livelihood and perception of the Somali pastoralist in Eastern Ethiopia

Kloos H (1982) Development, drought and famine in the Awash valley of Ethiopia. African Studies Review 25(4):21-48

Megersa B, Andre M, Angassa A, Anne VZ (2014) The role of livestock diversification in ensuring household food security under a changing climate in Borana, Ethiopia. Journal of Food science 6:15-28

Mercado DZ (2006) A manual in processing and reporting of participatory rural appraisal (PRA) data for natural resource management. GTZ, Pacific-German Regional Forestry Project, pp 3-23

Mohammed Y (2004) Pastoral and land tenure issues and development in the middle of Awash valley. Msc Thesis. Addis Ababa university, Addis Ababa, Ethiopia, $130 p$

Mohammed Y (2010) Is it a silent travel to death? Case of the Subaltran children of Lucy. Uppsala, Sweden

Musa L, Peters MA, Ahmed K, MK (2006) On farm characterization of Butana and Kenana cattle breed production systems in Sudan. Livestock Research for Rural Development, 18: Article No. 177. Retrieved July 16, 2011, from http:// www.Irrd.org/lrrd18/12/musa18177

Oba G (1998) Assessments of indigenous range management knowledge of the Borana pastoralists in southern Ethiopia. Borana Lowland Pastoral Development Program/GTZ, Consultancy Paper, Negelle/Borana May 1998

Solomon B, Abebe M (2014) Safeguarding pastoral land use rights in Ethiopia. Conference on land policy in Africa., 11-14 November, 2014, Addis Ababa

Stringer L, Reed MS (2007) Land degradation assessment in southern Africa: integrating local and scientific knowledge bases. Land degradation Dev 18:99-116

Sulieman H, Ahmed A (2013) Monitoring changes in pastoral resources in eastern Sudan: a synthesis of remote sensing and local knowledge., http://www. pastoralismjournal.com

Tafere K, Teklu G (2013) From the traditional Dagu to mobile and media technologies; communication and livelihood change among the Afar pastoralists of Ethiopia. Journal of Sociology and Anthropology 1(3):35-40

Teshome A, Ebro A, Nigatu L (2010) Traditional rangeland resource utilization practices and pastoralists' perceptions on land degradation in south-east Ethiopia. Tropical Grasslands 44:202-212

Tsegaye D (2010) Afar pastoralists in a changing rangeland environment. PhD Thesis. Norwegian University of Life Sciences, Norway, p 43

\section{Submit your manuscript to a SpringerOpen ${ }^{\circ}$ journal and benefit from:}

- Convenient online submission

- Rigorous peer review

- Immediate publication on acceptance

- Open access: articles freely available online

High visibility within the field

- Retaining the copyright to your article

Submit your next manuscript at $\boldsymbol{s p r i n g e r o p e n . c o m ~}$ 